\title{
Knowledge and awareness of Hepatitis B among first year Undergraduate Students of Three Dental Colleges in Haryana
}

\author{
Mohit Bansal ${ }^{1}$ \\ Shelja Vashisth ${ }^{2}$ \\ Nidhi Gupta ${ }^{3}$
}

\section{ABSTRACT}

Objective- To assess the Knowledge and awareness of Hepatitis B among first year undergraduate dental students of Haryana. Materials and Method- A cross sectional study was conducted in three colleges among 232 undergraduate dental students using a close ended questionnaire. Results- $84.9 \%$ of the students were aware regarding the spread of the disease. $52.2 \%$ of the students had got their initial vaccination while $23.7 \%$ of the student had complete vaccination against Hepatitis B. Conclusion- The overall knowledge and awareness regarding Hepatitis B was found to be lacking among dental students.

Keywords-knowledge, awareness, hepatitis B, disease.

\section{INTRODUCTION}

Hepatitis-B is an acute systemic infection with major pathology in the liver caused by Hepatitis B virus (HBV) ${ }^{1}$. It is a DNA virus classified in the virus family Hepadnaviridae, which enters the liver via blood stream. The infectious virus is $42-47 \mathrm{~nm}$ in diameter and circulates in blood in concentrations as high as 108 virions per $\mathrm{ml}^{2}$. It is present in high concentration in blood, serum, serum exudates, saliva, semen, vaginal fluid and most body fluids 1 . Hepatitis-B remains a major public health problem both in developed and developing countries like India ${ }^{3}$. About two billion people are affected with hepatitis $\mathrm{B}$ worldwide and more than 350 million have chronic, lifelong infection ${ }^{4}$. In India, about 45 millions population is hepatitis B infection carrier. More than 10,00,000 Indian children run a life time risk of becoming chronic carrier and about 1,00,000 Indians die from HBV complications annually ${ }^{1}$.

The practice of modern dentistry has contributed a lot in the increase of cases and spreading the disease in the society. It can be transmitted vertically, through household contacts or by unsafe injections ${ }^{5}$. The main etiology behind this is the high number of sharp injuries sustained by health care professionals during dental procedures or while drawing blood, giving injections or suturing ${ }^{6,7}$. In addition to this, those not wearing gloves while doing any procedure are at a greater risk of acquiring infection ${ }^{8}$. The life time risk of complications such as chronic hepatitis, cirrhosis and hepato-cellular carcinoma in subjects with chronic HBV infection is a major concern for health care personnel today ${ }^{9}$. Hepatitis B infections are common due to lapse in the sterilization technique of instruments or due to the improper hospital waste management as 10 to $20 \%$ health care waste is regarded hazardous and it may create variety of health risk $^{10}$.

Dental students being part of the health care professionals are also exposed to the same, when they come in contact with patients and contaminated instruments. Studies have shown that the risk of exposure for general dentists is about three to four times greater than that of general population ${ }^{11}$. Thus, proper knowledge of Hepatitis B infection is of uttermost importance for such professionals. Hence this study was taken to assess the knowledge and awareness of Hepatitis B among undergraduate dental students of Swami Devi Dyal Hospital and Dental College.

\section{MATERIALS AND METHOD}

The cross-sectional study was conducted among first year undergraduate dental students of three dental colleges (Swami Devi Dyal Hospital and Dental College, M.M. College of Dental Sciences and Research and BRS Dental College and Hospital) in Haryana. The ethical clearance was taken from the concerned authorities. A total of 223 voluntary students who were admitted in first year of their BDS degree and who were present at the time were included in the study. A pretested structured questionnaire was administered during a two months study period from February 2012 to April 2012, to collect information about the knowledge and awareness of students regarding hepatitis B. The data was analyzed using SPSS version 23.0.

\section{RESULTS}

A total of 223 students voluntarily participated in the study, of which $29.5 \%$ (66) were male and $70.5 \%$ (157) female students. Data regarding the knowledge and awareness of Hepatitis B infection among the students is described in 
Table-1.

As the data reveals majority of the students $54.7 \%$ knew that the vaccine is mandatory for dental professionals and

\section{Table 1: Knowledge and awareness assessment among} undergraduate students

\section{QUESTIONS}

1) Is Hepatitis $B$ an infectious disease

a) Yes

b) No

2) Do you know the mode of spread of Hepatitis $B$

a) Yes

b) No

3) If yes, how Hepatitis B can spread

a) Blood and blood products

b) Sharing a room

c) Sharing eating utensils

d) Sharing razor

e) Sexual intercourse

f) Syringes and needle pricks

g) Tattooing

h) Mother to child

i) Kissing

4) Can this disease cause liver cancer

a) Yes

b) No

c) Don't know

5) Is Hepatitis B test is must before surgery

a) Yes

b) No

c) Don't know

6) Is Hepatitis B vaccination mandatory for Dental professionals

a) Yes

b) No

c) Don't know

7) Do you have the knowledge of vaccination schedule of Hepatitis B

a) Yes

b) No

8) Have you ever been vaccinated for Hepatitis B

a) Yes

b) No

$7.3 \%$ of them didnot know about it, yet only $52.2 \%$ had their previous vaccination done for Hepatitis B. $47.8 \%$ of them knew about the vaccination schedule yet, only $23.7 \%$ had received all the four doses of Hepatitis $B$ vaccine, while $24.1 \%$ had received only one to two doses.

Majority of the students (73.1\%) agreed that Hepatitis B is an infectious disease which means that an infected person is a major source for transmitting these infections. $84.9 \%$ knew about the spread of the disease. About $55.2 \%$ students knew that Hepatitis B spreads mainly through blood related procedures (blood transfusion and needle injuries). $41.8 \%$ of the students were aware that Hepatitis B test is necessary before any surgery.

\section{DISCUSSION}

HBV infection is caused by DNA virus with incubation period of 21-135 days. In the present study, $73.1 \%$ of the students were aware that Hepatitis B is an infectious disease which was found to be similar as reported by Saini $\mathrm{R}$ etal ${ }^{12}$. Students regarded blood transfusion, syringes and needles to be an important factor for transmission of these deadly infections in this study. Studies suggest that accidental needle sticks are associated with the greatest risk for occupational transmission of blood-borne pathogens as reported by Berry $\mathrm{AJ}^{13}$, Sakowski $\mathrm{P}^{14}$, Simonsen L etal ${ }^{15}$ and Khuwaja $\mathrm{AK}^{16}$.

In the present study, $54.7 \%$ were aware about Hepatitis $B$ vaccination which was found to be very less as reported by Saini R etal 12 and Ogden GR etal ${ }^{17}$. In the present study, $23.7 \%$ of the students had complete vaccination against Hepatitis B, which was found to be less as reported by Biju IK, Sattar A etal ${ }^{18}$.

\section{CONCLUSION}

The present study concludes that there is lack of awareness among the dental students persuing the profession about the hazards of Hepatitis B. Moreover, all the students were not vaccinated against Hepatitis $\mathrm{B}$, which made them more vulnerable to the disease. Since the students are at increased risk of acquiring needle stick injury, and increased prevalence rate of Hepatitis B, thus the students should be routinely vaccinated upon entry into the college. It is recommended that a policy should be implemented for complete vaccination and health education of all the students in first year itself.

\section{AKNOWLEDGEMENT}

The authors thank all the students who participated in the study.

\section{REFERENCES}

1. Ray SK. Vaccine preventable diseases. In. Chaturvedi S, Jena TK eds. Epidemiology in maternal and child health, Preventive medicine. MME-101: IGNOU New Delhi 2003; 40-66.

2. Shepard CW, Simard EP, Finelli L, Fiore AE, Bell BP. Hepatitis B virus infection: epidemiology and vaccinations. Epidemiologic Reveiws 2006; 28:112-25.

3. Ganguly NK. Forward, prevention \& management of hepatitis B in India-Current trends and future. Indian Journal of Gasteroenterology 2000; 19 (3): 2-4.

4. Hepatitis B Fact Sheet No. 24. Geneva: World Health Organisation; 2006. Available from: http://www.who.int/ medicenter/factsheets/fs24/en. [last assessed on 2012 March 8].

5. Vadivale M, Tan TC, Ong CN. Sero-prevalence of hepatitis B infection among dental professionals. Singapore Medical Journal 1992; 33: 367-9.

6. Gillen M, McNary J, Lewis J, Davis M, Boyd A, Scheiller M, et al. Sharps related injuries in California healthcare facilities: pilot study results from the Sharps Injury Surveillance Registry. Infection 
Control and Hospital Epidemiology 2003; 24: 113-21.

7. O'Connell T, Hayes B. Occupational sharps injuries in a Dublin teaching hospital. Iranian Medical Journal 2003; 96:143-5.

8. Shiao J, Guo L, Mclaws ML. Estimation of the risk of bloodborne pathogens to health care workers after a needlestick injury in Taiwan. American Journal of Infection Control 2002; 30: 15-20.

9. Sarin SK, Singal AK. Preface: Prevention \& management of hepatitis $B$ in India- the need for consensus. Indian Journal of Gasteroenterology 2000; 19 (3): 1-5.

10. Taneja N, Biswal M .Safe disposal of infectious waste, Indian perspective. Journal of Hospital Infection Volume 62; 4: 525-6.

11. Cottone JA, Molinari JA. Hepatitis B Vaccine: an update. Journal of Califonia Dental Association 1989; 17:11-2.

12. Saini R, Saini S, Sugandha RS. Knowledge and awareness of Hepatitis B infection amongst the students of rural dental college Maharashtra, India. Annals of Nigerian Medicine 2010; 4(1):18-20.

13. Berry AJ. Needle stick and other safety issues. Anesthesiology Clinics of North America 2004; 22: 493-508.

14. Sakowski P. Protection of health care workers from occupational exposure to blood borne pathogens: problem approach in legislative and other documents adopted in different countries. Bol Association Med PR 2004; 55: 267-73.

15. Simonsen L, Kane A, Lloyd J, Zaffran M, Kane M. Unsafe injections in the developing world and transmission of bloodborne pathogens: a review. Bulletin World Health Organisation 1999; 77: 789-800.

16. Khuwaja Ak,Qureshi R,Fatimi Z. Knowledge and attitude about Hepatitis B and $\mathrm{C}$ among patients attending Family Medicine clinics in Karachi. Eastern Mediterranean Health Journal 2002; 8(6): 1-6.

17. Ogden GR, Laszlo J, Sivarajasingam V. Extent of Hepatitis B immunization among dental and medical students. British Medical Journal 1995; 311: 231

18. Biju IK, Sattar A, Kate M, etal Incidence and awareness of hepatitis B infection among and paramedical students. Indian Journal of Gastroenterology 2002; 21 (1): 104-5. 